\title{
Formation, Isolation and Characterization of Trehalose Dimycolates from Rhodococcus erythropolis Grown on $n$-Alkanes
}

\author{
By PETER RAPP, HANS BOCK, VICTOR WRAY AND FRITZ WAGNER \\ Gesellschaft für Biotechnologische Forschung mbH, 3300 Braunschweig-Stöckheim, Lehrstuhl \\ für Biochemie und Biotechnologie der Universität Braunschweig, Federal Republic of Germany
}

(Received 18 June 1979)

\begin{abstract}
Rhodococcus erythropolis DSM 43215 produced a surface-active trehalose lipid whose formation was induced by $n$-alkanes to a maximum of $2 \cdot 1 \mathrm{~g} \mathrm{l}^{-1}$ in a 501 batch culture on $2 \%(\mathrm{w} / \mathrm{v}) n$-alkanes of chain length $\mathrm{C}_{12}$ to $\mathrm{C}_{18}$. The glycolipid was extracted from the biomass with $n$-hexane and was purified by repeated chromatography on silica gel. It contained $\alpha, \alpha$-trehalose as the sole non-reducing sugar. The lipid moiety was characterized by ${ }^{13} \mathrm{C}$ nuclear magnetic resonance spectroscopy and mass spectrometry and consisted predominantly of saturated long-chain $\alpha$-branched $\beta$-hydroxy fatty acids (mycolic acids) ranging from $\mathrm{C}_{32} \mathrm{H}_{64} \mathrm{O}_{3}$ to $\mathrm{C}_{38} \mathrm{H}_{76} \mathrm{O}_{3}$, of which $\mathrm{C}_{34} \mathrm{H}_{68} \mathrm{O}_{3}$ and $\mathrm{C}_{35} \mathrm{H}_{70} \mathrm{O}_{3}$ predominated. The molar ratio of trehalose to mycolic acids was $1: 2 .{ }^{13} \mathrm{C}$ nuclear magnetic resonance analysis of the $O$ hexamethyltrehalose obtained by saponification of the permethylated trehalose dimycolates revealed, with the aid of deuterium exchange, that the ester linkages of mycolic acids are to both primary alcohol groups at the C-6 and C- $6^{\prime}$ positions of the trehalose.
\end{abstract}

\section{INTRODUCTION}

Mycolic acids are long-chain $\alpha$-branched $\beta$-hydroxy fatty acids that are found as cell wall constituents of mycobacteria, nocardiae and corynebacteria (Kanetsuna \& Bartoli, 1972; Goodfellow et al., 1976; Minnikin et al., 1975; Minnikin \& Goodfellow, 1976). They are also part of the so-called 'cord factors', trehalose 6,6'-dimycolates, which are formed by certain actinomycetes and coryneform bacteria. The size and structure of the mycolic acids in the cord factors vary according to the source of the trehalose lipid (Lederer, 1976; Asselineau \& Asselineau, 1978). The number of carbon atoms in the mycolic acid residues ranges from $C_{70}$ to $C_{90}$ in the cord factors of mycobacteria (Lederer, 1967) to $C_{28}$ to $C_{32}$ in those of Corynebacterium diphtheriae (Senn et al., 1967). From the emulsion layer of Arthrobacter paraffineus grown on $n$-alkane, trehalose dimycolates were isolated with mycolic acid residues of unknown substitution pattern with a composition ranging from $\mathrm{C}_{28}$ to $\mathrm{C}_{38}$ (Suzuki et al., 1969). The present interest in trehalose lipids has centred almost exclusively on mycobacterial cord factors, because of their toxic properties (Lederer, 1976; Barksdale \& Kim, 1977). During recent work on oil recovery from subterranean formations employing flooding water with a non-ionic surfactant (Wagner et al., 1978; Rapp et al., 1977) and on the uptake of hydrocarbons by bacteria (Rapp \& Wagner, 1976), a surfaceactive trehalose lipid was found in the culture broth of a Rhodococcus erythropolis strain grown on $n$-alkanes. The formation, isolation and characterization of the glycolipid, $6,6^{\prime}$-trehalose dimycolate, are described in this paper. 


\section{METHODS}

Organism and growth. Rhodococcus erythropolis DSM 43215 was isolated from an oil-containing soil sample and identified by R. M. Kroppenstedt. Previously the bacterium had been tentatively called Nocardia rhodochrous (Rapp \& Wagner, 1976; Rapp et al., 1977; Wagner et al., 1978). It was grown at $30^{\circ} \mathrm{C}$ in the

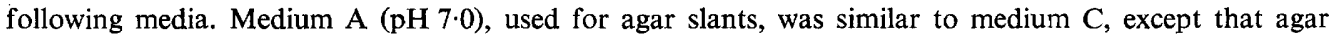
$\left(20 \mathrm{~g}^{-1}\right)$ and $\left(\mathrm{NH}_{4}\right)_{2} \mathrm{HPO}_{4}\left(1 \cdot 5 \mathrm{~g}^{-1}\right)$ were added and $\left(\mathrm{NH}_{4}\right)_{2} \mathrm{SO}_{4}, \mathrm{CaCl}_{2}$ and $\mathrm{FeCl}_{3}$ were omitted. Medium $\mathrm{B}$ (pH 7.0), used for shake-flask cultures, had the same composition as medium A except that agar was omitted. Medium $\mathrm{C}$ ( $\mathrm{pH} \mathrm{6.8),} \mathrm{used} \mathrm{for} 10$ and 501 batch cultivations, contained ( $\mathrm{g}^{-1}$ in deionized water): yeast extract, $1.0 ; \mathrm{K}_{2} \mathrm{HPO}_{4} .3 \mathrm{H}_{2} \mathrm{O}, 1 \cdot 0 ; \mathrm{KH}_{2} \mathrm{PO}_{4}, 0.5 ; \mathrm{Na}_{2} \mathrm{HPO}_{4} .2 \mathrm{H}_{2} \mathrm{O}, 0 \cdot 5 ;\left(\mathrm{NH}_{4}\right)_{2} \mathrm{SO}_{4}, 2 \cdot 0 ; \mathrm{MgSO}_{4} .7 \mathrm{H}_{2} \mathrm{O}, 0 \cdot 1 ;$ $\mathrm{CaCl}_{2} .2 \mathrm{H}_{2} \mathrm{O}, 0.05 ; \mathrm{FeCl}_{3} .6 \mathrm{H}_{2} \mathrm{O}, 0.02$; and trace metal stock solution, $1 \mathrm{ml} \mathrm{l^{-1 }}$. Trace metal stock solution contained ( $\mathrm{g} \mathrm{l}^{-1}$ in distilled water): $\mathrm{ZnSO}_{4} \cdot 7 \mathrm{H}_{2} \mathrm{O}, 11 \cdot 0 ; \mathrm{MnSO}_{4} \cdot \mathrm{H}_{2} \mathrm{O}, 6 \cdot 0 ; \mathrm{FeSO}_{4} \cdot 7 \mathrm{H}_{2} \mathrm{O}, 1 \cdot 0 ; \mathrm{CoSO}_{4} \cdot 7 \mathrm{H}_{2} \mathrm{O}$, $0 \cdot 3 ; \mathrm{CuSO}_{4} .5 \mathrm{H}_{2} \mathrm{O}, 0.04 ; \mathrm{H}_{3} \mathrm{BO}_{3}, 0.06 ; \mathrm{KI}, 0.001$; EDTA, 5.0. $n$-Alkanes used as substrate were composed of $0.5 \% \mathrm{C}_{12}, 4.4 \% \mathrm{C}_{13}, 25.6 \% \mathrm{C}_{14}, 28.6 \% \mathrm{C}_{15}, 24.7 \% \mathrm{C}_{16}, 14.7 \% \mathrm{C}_{17}$ and $1.5 \% \mathrm{C}_{18}$.

The organism was grown for $24 \mathrm{~h}$ on an agar slant of medium A supplemented with $1 \%(\mathrm{w} / \mathrm{v})$ carbon source. The bacteria were washed off into $500 \mathrm{ml}$ shake-flasks containing $100 \mathrm{ml}$ medium B with $1 \%(\mathrm{w} / \mathrm{v})$ carbon source and cultured for $24 \mathrm{~h}$ on a rotating shaker at $100 \mathrm{rev} . \mathrm{min}^{-1} ; 2.5 \mathrm{ml}$ of this culture was inoculated into $250 \mathrm{ml}$ medium B with $1 \%(\mathrm{w} / \mathrm{v})$ of the same carbon source in 11 shake-flasks and cultivated for $24 \mathrm{~h}$ with shaking as before.

For 101 batch cultivations, $500 \mathrm{ml}$ of a culture grown on medium B, as described above, was inoculated into 9.51 medium $\mathrm{C}$ with $2 \%(\mathrm{w} / \mathrm{v})$ carbon source contained in a sparged and baffled 141 fermenter (type b10, Giovanola Frères, Monthey, Switzerland) equipped with a turbine system of two 6-flat-bladed impellers. The culture was aerated at 1.0 vol. air (vol. liquid) ${ }^{-1} \mathrm{~min}^{-1}$ and stirred at $300 \mathrm{rev}$. $\mathrm{min}^{-1}$. The $\mathrm{pH}$ was automatically controlled at 6.8 by addition of $3.8 \mathrm{M}-\mathrm{NH}_{4} \mathrm{OH}$.

For large-scale production of trehalose lipid, a 91 batch culture, grown as described above for $16 \mathrm{~h}$ on medium $\mathrm{C}$ with $2 \%(\mathrm{w} / \mathrm{v}) n$-alkanes (chain length $\mathrm{C}_{12}$ to $\mathrm{C}_{18}$ ), was inoculated into $411 \mathrm{medium} \mathrm{C}$ supplemented with $2 \%(\mathrm{w} / \mathrm{v}) n$-alkanes $\left(\mathrm{C}_{12}\right.$ to $\left.\mathrm{C}_{18}\right)$ contained in an 801 fermenter (type b50, Giovanola Frères) equipped with a draft tube and driven by a specially constructed propeller (Intensor system, Giovanola Frères) at $1500 \mathrm{rev}$. $\mathrm{min}^{-1}$. The culture was aerated at $1.66 \mathrm{vol}$. air (vol. liquid) ${ }^{-1} \mathrm{~min}^{-1}$ and the $\mathrm{pH}$ was automatically adjusted by titration with $14 \cdot 7 \mathrm{M}-\mathrm{NH}_{4} \mathrm{OH}$.

Determination of $\mathrm{O}_{2}$ and $\mathrm{CO}_{2}$ in the outlet air. $\mathrm{O}_{2}$ and $\mathrm{CO}_{2}$ in the exit stream of the fermenter were monitored by a paramagnetic oxygen analyser (Oxygor; Maihak, Hamburg, F.R.G.) and a non-dispersive infrared photometer (Unor; Maihak). The range of $\mathrm{O}_{2}$ concentration for analysis was chosen between 19 and $21 \%$ and the measuring range of $\mathrm{CO}_{2}$ concentration was set from 0 to $5 \%$.

Determination of cell growth. Culture broth $(10 \mathrm{ml})$ was thoroughly mixed with $10 \mathrm{ml}$ ethanol/butan-1-ol/ chloroform (10:10:1, by vol.) and centrifuged at $9600 \mathrm{~g}$ for $20 \mathrm{~min}$; the pellet was washed with $10 \mathrm{ml}$ water and dried at $50^{\circ} \mathrm{C}$ under reduced pressure to a constant weight.

Determination of the trehalose lipid content. The formation of the trehalose lipid was followed by extracting the culture broth or biomass three times with chloroform/methanol $(2: 1, \mathrm{v} / \mathrm{v})$ or $n$-hexane. The extract was washed twice with water and the sugar content was determined by the anthrone method (Hodge $\&$ Hofreiter, 1962) using trehalose as standard.

Saponification. Trehalose lipid and its derivatives (about $400 \mathrm{mg}$ ) were dissolved in diethyl ether $(10 \mathrm{ml})$ and treated with $0.5 \mathrm{M}-\mathrm{NaOH}$ in $90 \%$ ethanol $(15 \mathrm{ml})$ for $12 \mathrm{~h}$ at $60^{\circ} \mathrm{C}$. After the addition of water $(10 \mathrm{ml})$, the organic solvent layer was separated and then evaporated. The residue was acidified with $\mathrm{HCl}$ and extracted with diethyl ether. This procedure separated the fatty acids from the sugars. The fatty acids were purified by thin-layer chromatography with solvent system B (see below). The aqueous solution containing sugar was desalted by ion-exchange chromatography using a mixed bed of Amberlite IRA-400 ( $\mathrm{OH}^{-}$form) and IR-120 ( $\mathrm{H}^{+}$form).

Acid hydrolysis. Trehalose was hydrolysed in $0.5 \mathrm{M}-\mathrm{H}_{2} \mathrm{SO}_{4}$ at $90^{\circ} \mathrm{C}$ under $\mathrm{N}_{2}$ for $6 \mathrm{~h} . \mathrm{BaCO}_{3}$ was then added to neutralize the acid and the resulting solution (of glucose) was desalted by ion-exchange chromatography, as described for saponification.

Trimethylsilylation, methylation and acetylation. Trimethylsilyl derivatives of the sugars were prepared as described by Brobst (1972) and the trehalose lipid by the method of Kamerling et al. (1970).

Methyl esters of mycolic acid were prepared with diazomethane. Permethylation of the trehalose lipid was carried out by a modified method of Ioneda et al. (1970). The dimethylformamide used for this procedure was dried by refluxing with calcium hydride for $2 \mathrm{~h}$ followed by distillation under dry $\mathrm{N}_{2}$. Trehalose lipid $(1.65 \mathrm{~g})$ was dissolved in the dry dimethylformamide $(30 \mathrm{ml})$ and sodium hydride $(0.5 \mathrm{~g})$ in iodomethane $(10 \mathrm{ml})$ was added; the reaction mixture was agitated at $50^{\circ} \mathrm{C}$ under dry $\mathrm{N}_{2}$ for $3.5 \mathrm{~h}$. The methylated products were extracted with chloroform, washed with water and precipitated with methanol. The methylated 
trehalose lipid was dissolved in $n$-hexane/diethyl ether $(3: 2, \mathrm{v} / \mathrm{v})$ and further purified by column chromatography on silica gel $60(30 \mathrm{~cm} \times 2 \mathrm{~cm}$ diam., 230 to 400 mesh, ASTM, Merck). Elution with $n$-hexane/diethyl ether $(3: 2, v / v)$ was followed by thin-layer chromatography with solvent system $C$ (see below). In this way $50 \%$ of the the trehalose lipid was permethylated and the remaining partially methylated products were again subjected to the methylation procedure.

The mycolic acids were permethylated by the method of Hakomori (1964) using methylsulphinylcarbanion (Corey \& Chaykovsky, 1962). The methylated products were precipitated with cold acetone and purified by thin-layer chromatography with solvent system C. In this way $50 \%$ of the mycolic acids were permethylated; the non- and partially methylated acids were subjected once more to the methylation procedure.

Thin-layer chromatography. Thin-layer chromatography (t.1.c.) was performed on Merck silica gel 60 and $60 \mathrm{~F}_{254}$ plates. For analytical purposes the silica gel was $0.25 \mathrm{~mm}$ thick, and for preparative plates it was $2 \mathrm{~mm}$ thick. The trehalose lipid, its derivatives and related compounds were chromatographed with the following solvent systems: the trehalose lipid with solvent system $A$, chloroform/methanol/water $(65: 15: 2$, by vol.); mycolic acids with solvent system B, chloroform/propan-2-ol/glacial acetic acid (70:5:1, by vol.); permethylated trehalose lipid and $O$-methyl fatty acid methyl esters with solvent system $\mathrm{C}$, petroleum ether (b.p. 60 to $\left.80^{\circ} \mathrm{C}\right) /$ diethyl ether/acetone $(80: 30: 10$, by vol.); mono- and disaccharides with solvent system D, propan-2-ol/water $(85: 15, \mathrm{v} / \mathrm{v})$. Sugars, trehalose lipid and the corresponding derivatives were detected by spraying with anisaldehyde $/ \mathrm{H}_{2} \mathrm{SO}_{4}$ reagent (Krebs et al., 1967). Mycolic acids and their derivatives were detected by spraying with 2,7-dichlorofluorescein/molybdic phosphoric acid reagent or $50 \%(\mathrm{w} / \mathrm{v}) \mathrm{H}_{2} \mathrm{SO}_{4}$ (Krebs et al., 1967).

Gas-liquid chromatography. Gas-liquid chromatography (g.l.c.) of trimethylsilylated (TMS) sugars was carried out with a Perkin Elmer gas chromatograph M900 equipped with a flame ionization detector. A stainless-steel column $(200 \mathrm{~cm} \times 0.27 \mathrm{~cm}$ diam.) packed with $1 \% \mathrm{SE} 52$ on Chromosorb $\mathrm{G}$ was used. The column was operated for the chromatography of TMS-glucose at $120^{\circ} \mathrm{C}$ and for analysis of TMS-trehalose at $190{ }^{\circ} \mathrm{C}$ with a $\mathrm{N}_{2}$ flow rate of $50 \mathrm{ml} \mathrm{min}-1$. G.l.c. analysis of the $O$-methyl mycolic acid methyl esters was performed with a Hewlett Packard 5700A gas chromatograph fitted with a flame ionization detector and a stainless-steel column $(180 \mathrm{~cm} \times 0.27 \mathrm{~cm}$ diam.) packed with $10 \% \mathrm{SE} 30$ on Chromosorb W. The column was operated at $300{ }^{\circ} \mathrm{C}$ with a $\mathrm{N}_{2}$ flow rate of $29 \mathrm{ml} \mathrm{min}^{-1}$. Peak area measurements were made with an Autolab system IV computing integrator (Spectra Physics).

Mass spectrometry. Mass spectra were recorded using an A.E.I. MS-9 instrument operated at $8 \mathrm{kV}$ accelerating voltage and $70 \mathrm{eV}$ ionizing voltage. Samples were inserted directly into the ion source at the minimum temperature.

${ }^{13} \mathrm{C}$ nuclear magnetic resonance (n.m.r.) spectroscopy. Proton noise and single frequency off-resonance proton decoupled (SFORD) ${ }^{13} \mathrm{C}$ n.m.r. spectra were obtained in the Fourier transform mode with a Varian XL-100-12 spectrometer at $25 \cdot 16 \mathrm{MHz}$ and locked to the deuterium resonance $(15 \cdot 40 \mathrm{MHz})$ of the solvent, $\mathrm{CDCl}_{3}$. The instrument was interfaced to a Varian 620-L computer equipped with a moving head disc together with complementary software. Peak positions were considered to be accurate to better than 0.04 p.p.m. Tetramethylsilane was used as internal standard. For the ${ }^{13} \mathrm{C}$ n.m.r. spectra of $O$-hexamethyltrehalose. hexadeuterodimethyl sulphoxide was used as solvent.

\section{RESULTS}

\section{Formation of trehalose lipid by Rhodococcus erythropolis}

In a 501 batch culture of Rhodococcus erythropolis on $2 \%(\mathrm{w} / \mathrm{v}) n$-alkanes (chain length $\mathrm{C}_{12}$ to $\mathrm{C}_{18}$ ) growth started almost immediately whereas the trehalose lipid formation showed a lag phase of about $4 \mathrm{~h}$ (Fig. 1). Large clumps of bacteria were observed after about $10 \mathrm{~h}$ which retarded and finally stopped growth and trehalose lipid formation. This cessation of growth was shown by a sharp drop in $Q_{\mathrm{O}_{2}}$ and $Q_{\mathrm{Co}_{2}}$ values (Fig. 1). When the largest clumps had disintegrated to much smaller cell aggregates after about $20 \mathrm{~h}$, growth and trehalose lipid formation recommenced and after $40 \mathrm{~h}$ reached maximal amounts of $19 \mathrm{~g}$ dry wt cells $\mathrm{l}^{-1}$ and $2 \cdot 1 \mathrm{~g}$ trehalose lipid $\mathrm{l}^{-1}$. When the organism was grown in $10 \mathrm{l}$ batch cultures for $4 \mathrm{~d}$ with $2 \%(\mathrm{w} / \mathrm{v})$ glucose or glycerol as carbon source, the trehalose lipid concentration never exceeded 0.4 to $0.8 \mathrm{mg}^{-1}$. This indicates that the formation of trehalose lipid by Rhodococcus erythropolis is probably induced by $n$-alkanes. 


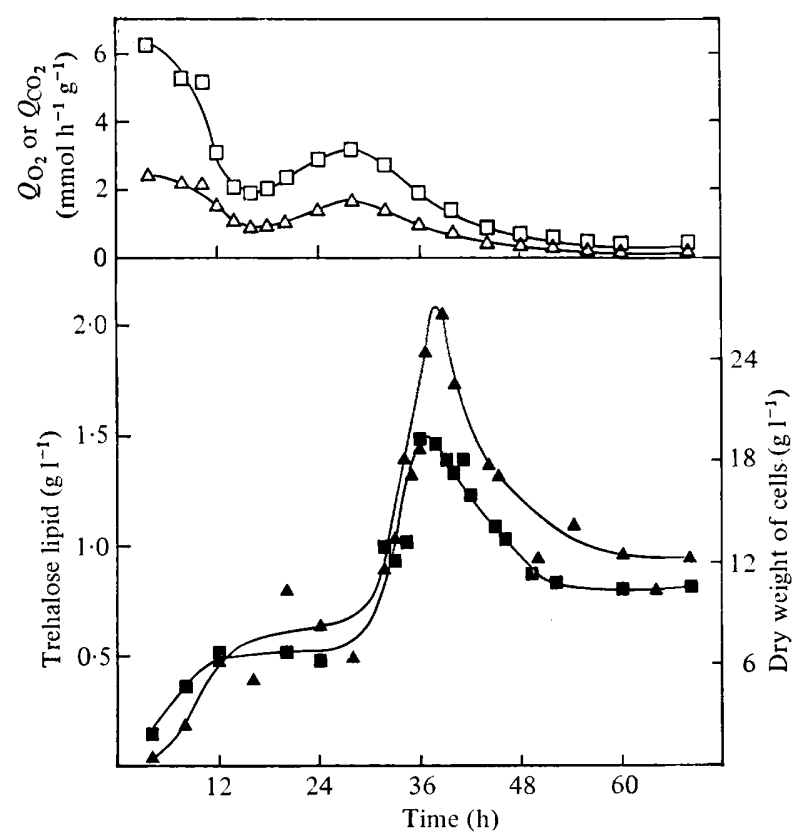

Fig. 1. Trehalose lipid formation by Rhodococcus erythropolis DSM 43215 during a 501 batch cultivation on $n$-alkanes. For details, see Methods. $\boldsymbol{\Delta}$, Trehalose lipid; $\mathbf{\square}$, dry weight of cells; $\square$, oxygen consumption $\left(Q_{\mathrm{O}_{2}}\right) ; \triangle$, carbon dioxide production $\left(Q_{\mathrm{CO}_{2}}\right)$.

\section{Isolation and purification of trehalose lipid}

The biomass was extracted with $n$-hexane until no further trehalose lipid could be removed; this was checked by t.l.c. with solvent system A. The viscous residue obtained by evaporation of the $n$-hexane at $30^{\circ} \mathrm{C}$ under reduced pressure was dissolved in a small amount of chloroform and applied to a silica gel 60 column $(25 \mathrm{~cm} \times 15 \mathrm{~cm}$ diam., 70 to 230 mesh, ASTM, Merck). Residual $n$-alkanes and possible other non-polar compounds, as well as a yellow pigment, were eluted with 2 bed vol. chloroform, followed by 2 bed vol. chloroform/acetone $(2: 1, \mathrm{v} / \mathrm{v})$. Trehalose lipid was finally eluted with acetone, the elution being followed by the anthrone reaction (Hodge \& Hofreiter, 1962) and t.l.c. with solvent system A. After removing the acetone by evaporation at $30^{\circ} \mathrm{C}$ under reduced pressure, trehalose lipid was dissolved in a small amount of chloroform/acetone $(2: 1, \mathrm{v} / \mathrm{v})$ and chromatographed on a silica gel 60 column $(33 \mathrm{~cm} \times 2 \mathrm{~cm}$ diam., 230 to $400 \mathrm{mesh}$, ASTM, Merck) with chloroform/acetone $(2: 1, \mathrm{v} / \mathrm{v})$. The elution was followed as described above. Purified trehalose lipid was also obtained by dissolving the lipid-containing residue, obtained after the first chromatography on silica"gel, in chloroform and precipitating the trehalose lipid by adding acetone dropwise. The purified trehalose lipid, examined by t.l.c. with solvent system $\mathrm{A}$, showed a single spot with an $R_{F}$ value of 0.46 . It melted at 89 to $91{ }^{\circ} \mathrm{C}$ and had a specific rotation $[\alpha]_{578}^{25}$ of $+78 \cdot 6^{\circ}$.

\section{Nature of the sugar moiety}

The positive reaction of the purified compound with the anthrone reagent (Hodge \& Hofreiter, 1962) suggested that one of its components was a carbohydrate. The lipid was therefore saponified and the water-soluble fraction was analysed for sugars. No reducing sugars were detected by the 3,5-dinitrosalicylic acid method (Brunner, 1964) and t.l.c revealed trehalose to be the sugar moiety of the glycolipid. Further evidence that $\alpha, \alpha-$ trehalose is a constituent of the glycolipid was provided by g.l.c. of the trimethylsilylated sugar moiety. This finding was confirmed by acidic hydrolysis of the carbohydrate moiety; 
Table. $1 .{ }^{13} \mathrm{C}$ nuclear magnetic resonance signals of mycolic acid methyl esters

\begin{tabular}{|c|c|c|}
\hline $\begin{array}{l}{ }^{13} \mathrm{C} \text { chemical } \\
\text { shift } \\
\text { (p.p.m.) }\end{array}$ & $\begin{array}{l}\text { Multiplicity } \\
\text { in SFORD } \\
\text { spectrum* }\end{array}$ & Assignment \\
\hline & & $\mathrm{OH}$ \\
\hline $176 \cdot 26$ & $\mathrm{~s}$ & $\begin{array}{l}-\stackrel{\perp}{\mathrm{C}} \mathrm{H}-\mathrm{I} \mathrm{CH}-\mathrm{COOCH}_{3} \\
\mathrm{OH}\end{array}$ \\
\hline $72 \cdot 36$ & $\mathrm{~d}$ & $\begin{array}{l}-\stackrel{\prime}{\mathrm{C}} \mathrm{H}-\mathrm{I} \mathrm{C} H-\mathrm{COOCH}_{3} \\
\mathrm{OH}\end{array}$ \\
\hline $51 \cdot 46$ & $\mathrm{q}$ & $\begin{array}{l}-\stackrel{\mathrm{C}}{\mathrm{C}} \mathrm{H}-\stackrel{1}{\mathrm{C}} \mathrm{H}-\mathrm{COOCH}_{3} \\
\mathrm{OH}\end{array}$ \\
\hline $51 \cdot 12$ & $\mathrm{~d}$ & $\begin{array}{c}-\mathrm{C} H-\stackrel{I}{\mathrm{C}} \mathrm{H}-\mathrm{COOCH}_{3} \\
\mathrm{OH}\end{array}$ \\
\hline $35 \cdot 71$ & $\mathrm{t}$ & $-\mathrm{CH}_{\mathbf{2}}-\mathrm{CH}-\mathrm{CH}-$ \\
\hline $31 \cdot 99$ & $\mathrm{t}$ & $-\mathrm{CH}_{2}-\mathrm{CH}_{2}-\mathrm{CH}_{3}$ \\
\hline $30 \cdot 38-29 \cdot 77$ & $\mathrm{t}$ & $\begin{array}{l}-\mathrm{CH}_{2}-\mathrm{CH}_{2}-\mathrm{CH}_{2}- \\
\stackrel{1}{\mathrm{OH} C \mathrm{H}_{2}}\end{array}$ \\
\hline $27 \cdot 50$ & $\mathrm{t}$ & $\begin{array}{r}-\mathrm{CH}-\mathrm{CH}-\mathrm{COOCH}_{3} \\
\mathrm{OH}\end{array}$ \\
\hline $25 \cdot 78$ & $\mathrm{t}$ & $-\mathrm{CH}_{2}-\mathrm{CH}_{2}-\stackrel{\text { CH}}{\mathrm{C}}-$ \\
\hline $22 \cdot 74$ & $\mathrm{t}$ & $-\mathrm{CH}_{2}-\mathrm{CH}_{2}-\mathrm{CH}_{3}$ \\
\hline $14 \cdot 12$ & $\mathrm{q}$ & $-\mathrm{CH}_{2}-\mathrm{CH}_{2}-\mathrm{CH}_{3}$ \\
\hline
\end{tabular}

* s, Singlet; d, doublet; t, triplet; q, quartet.

the sugar obtained exhibited reducing properties and was identified as D-glucose by t.l.c. and g.l.c.

The ${ }^{13} \mathrm{C}$ n.m.r. shifts of the hexamethyltrehalose derivative (Table 4) were compatible with these findings. Thus, the observation of only six signals (Table 4, also see later) confirmed that the disaccharide is made up of two identical monosaccharide units with either an $\alpha, \alpha$ or $\beta, \beta$ inter-ring linkage. Comparison can be made with previous ${ }^{13} \mathrm{C}$ n.m.r. data for the $\alpha, \alpha$ - and $\beta, \beta$-trehalose octa-acetates (Schilling et al., 1975). As the $\gamma$ and longer range effects of methylation and acetylation on ${ }^{13} \mathrm{C}$ shifts are similar (Bremser et al., 1978) (to \pm 1 p.p.m., compare butan-1-ol, butyl methyl ether and butylacetate), the shift of C-1 of 92.4 p.p.m. corresponds to an $\alpha, \alpha$ inter-ring linkage (a $\beta, \beta$ linkage would give a shift of $97 \pm 1$ p.p.m.).

\section{Nature of the lipid moiety}

The lipophilic components of the trehalose lipid were isolated, after saponification, as free acids and purified by t.l.c. with solvent system B $\left(R_{F} 0 \cdot 42\right)$. The specific optical rotation $[\alpha]_{578}^{25}\left(\mathrm{CHCl}_{3}\right)$ was $+8 \cdot 4^{\circ}$. The fatty acids were esterified with diazomethane, purified by t.l.c. with solvent system $\mathrm{C}\left(R_{F} 0 \cdot 24\right)$ and analysed by ${ }^{13} \mathrm{C}$ n.m.r. spectroscopy and mass spectrometry.

The signals in the ${ }^{13} \mathrm{C}$ n.m.r. spectra were assigned from their multiplicity in the SFORD ${ }^{13} \mathrm{C}$ spectra which immediately allowed the identification of the carbons as either methyl (quartet), methylene (triplet), methine (doublet) or quaternary (singlet) carbons. Comparison of the shifts with literature data (Bremser et al., 1978; Stothers, 1972) allowed the assignments given in Table 1 to be made and indicated the presence of a carboxylic acid methyl ester group, branching at the $\alpha$-carbon and a hydroxyl group in the $\beta$-position. The spectra also showed many methylene signals and two 'different methyl signals. In several preparations of various derivatives a minor peak at 130.0 p.p.m. was observed and was 


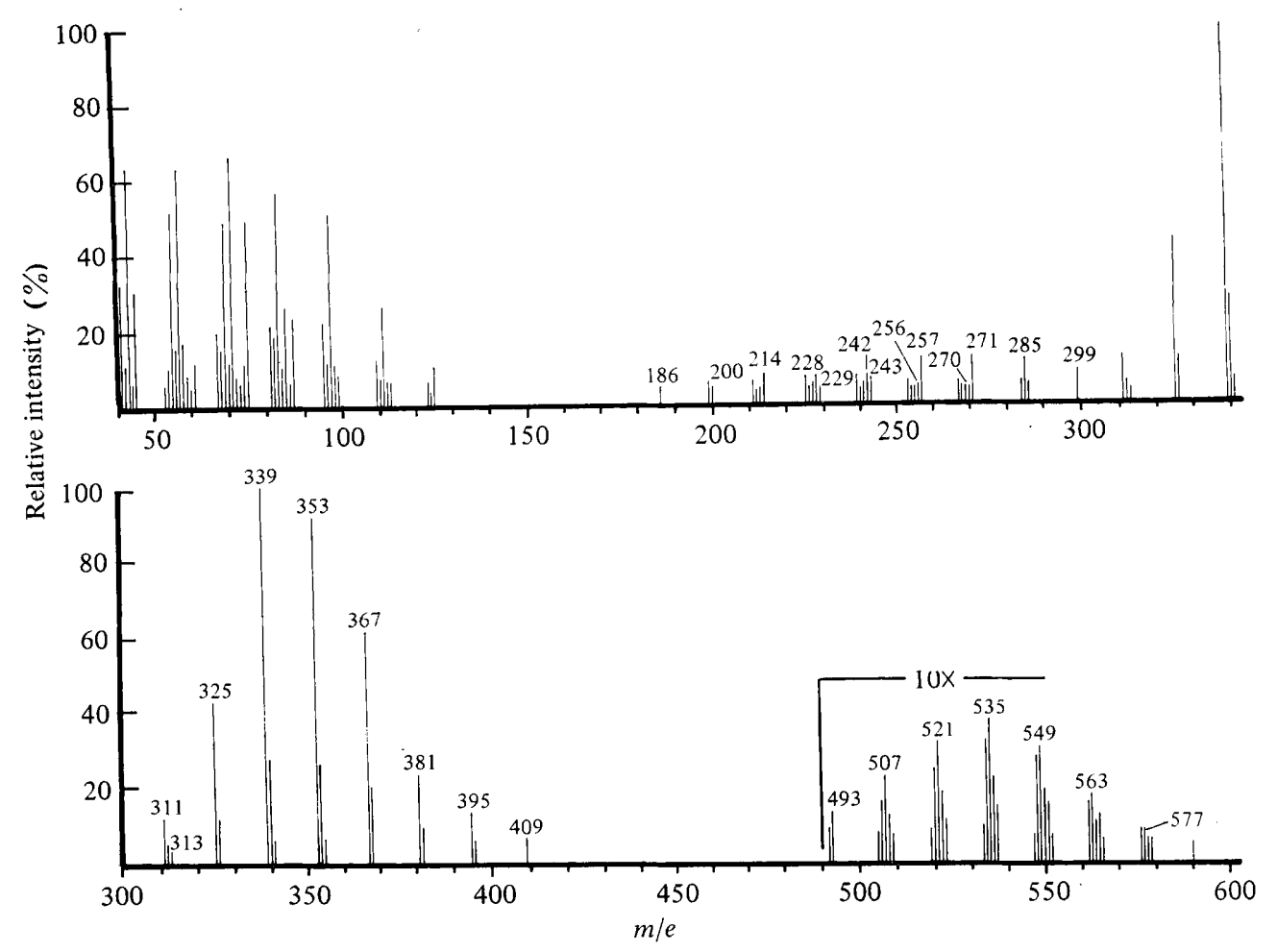

Fig. 2. Mass spectrum of permethylated mycolic acids.

attributable to a double-bond in the side-chain. From these results we concluded that the major component of the lipid moiety consisted of saturated mycolic acids. These acids are long-chain saturated fatty acids with an alkyl branch in the 2-position and a hydroxyl group in the 3-position.

The mass spectral data were consistent with these conclusions. Thus mass spectral fragmentation of $O$-methyl mycolic acid methyl ester $\left(R_{F} 0 \cdot 54\right.$, solvent system C) caused cleavages as summarized in the following scheme:

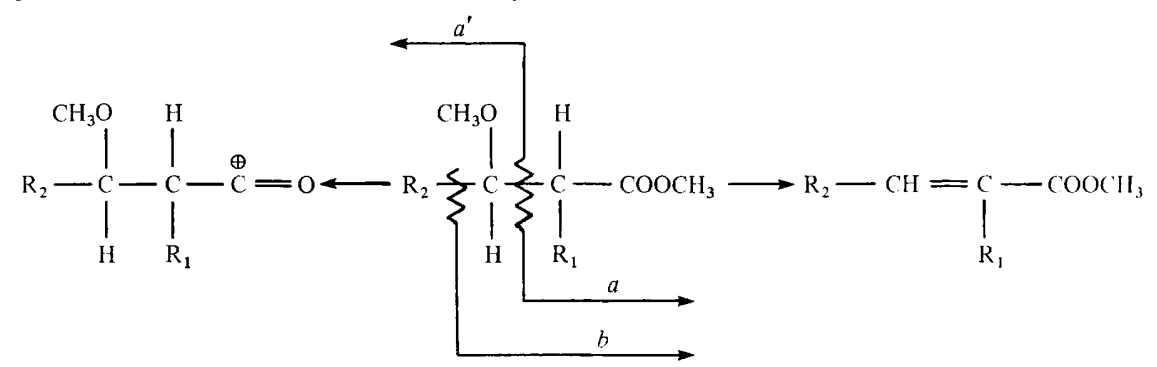

The mass spectrum of the permethylated mycolic acids is shown in Fig. 2 and the peaks obtained are summarized in Table 2. Molecular ions were absent and the highest peaks corresponded to $\mathrm{M}-31\left[\mathrm{R}_{2}-\mathrm{CH}\left(\mathrm{OCH}_{3}\right)-\mathrm{CH}\left(\mathrm{R}_{1}\right)-\stackrel{\oplus}{\mathrm{C}}=\mathrm{O}\right.$ ] and $\mathrm{M}-32$ [anhydromycolic acid methyl ester]. The overall composition of the mycolic acids was derived from the peaks $\mathrm{M}-31$ and $\mathrm{M}-32$ and is represented by a homologous series ranging from $\mathrm{C}_{32} \mathrm{H}_{64} \mathrm{O}_{3}$ to $\mathrm{C}_{38} \mathrm{H}_{76} \mathrm{O}_{3}$. The two series of peaks attributable to fragments $a+\mathrm{H}$ and $b$ give the composition of the side-chain $\mathrm{R}_{1}$, represented by the homologous series $\mathrm{C}_{8} \mathrm{H}_{17}$ to $\mathrm{C}_{14} \mathrm{H}_{29}$. The composition of the main-chain $\mathrm{R}_{2}$ was derived from a series of peaks from $m / e 311$ to 409 , which corresponded to the homologous series $\mathrm{C}_{19} \mathrm{H}_{39}$ to $\mathrm{C}_{26} \mathrm{H}_{53}$ for $\mathrm{R}_{2}$. 
Table 2. Peaks in the mass spectra of permethylated mycolic acids

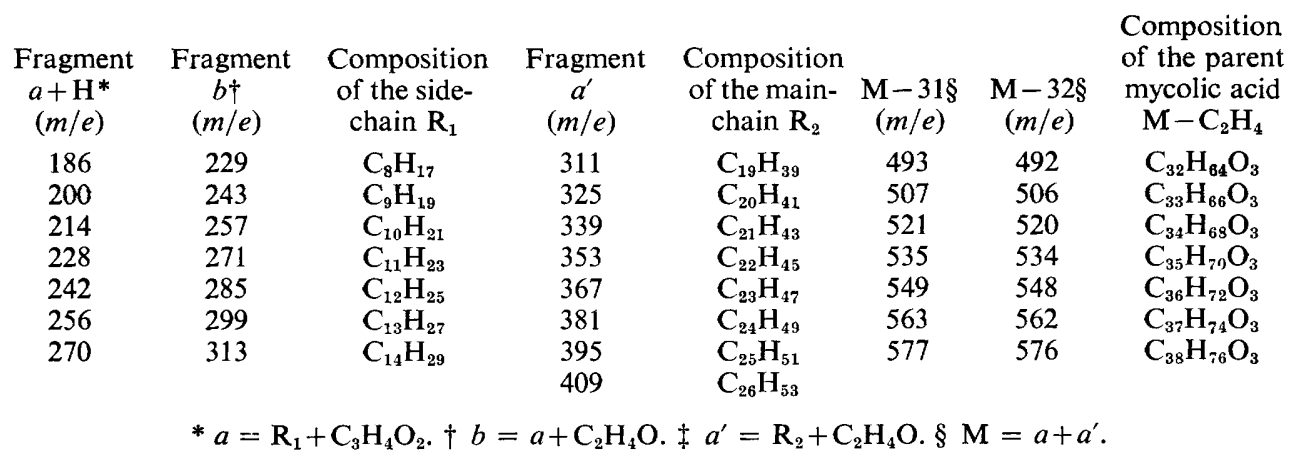

Since the relative proportions of the mycolic acids could not be determined exactly by mass spectrometry, the permethylated mycolic acids were analysed by g.l.c. As shown in Table 3, the predominant mycolic acids were $\mathrm{C}_{35} \mathrm{H}_{70} \mathrm{O}_{3}$ and $\mathrm{C}_{34} \mathrm{H}_{68} \mathrm{O}_{3}$ with smaller amounts of $\mathrm{C}_{36} \mathrm{H}_{72} \mathrm{O}_{3}$. In the mass spectrum of $O$-methyl mycolic acid methyl esters (Fig. 2), the most intense peaks were at $m / e 339$ and 353 representing the most abundant main-chains $\left(\mathbf{R}_{2}\right)$ $\mathrm{C}_{21} \mathrm{H}_{43}$ and $\mathrm{C}_{22} \mathrm{H}_{45}$. The peaks at $m / e 257,271$ and 285 were the most intense peaks attributable to fragments which corresponded to the side-chain $\left(\mathrm{R}_{1}\right)$ and represented $\mathrm{C}_{10} \mathrm{H}_{21}$, $\mathrm{C}_{11} \mathrm{H}_{23}$ and $\mathrm{C}_{1.2} \mathrm{H}_{25}$. Thus, the predominant mycolic acids, $\mathrm{C}_{34} \mathrm{H}_{68} \mathrm{O}_{3}$ and $\mathrm{C}_{35} \mathrm{H}_{70} \mathrm{O}_{3}$, have the following chain lengths:

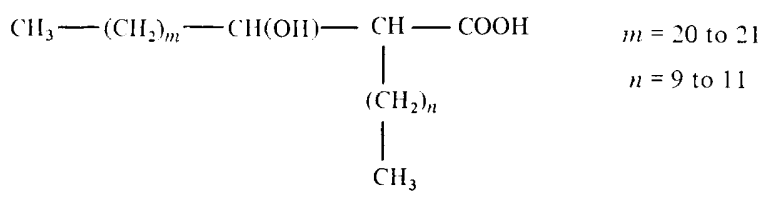

\section{Permethylated trehalose lipid}

The mass spectrum of the permethylated trehalose lipid $\left(R_{F} 0 \cdot 47\right.$, solvent system $\left.C\right)$ is shown in Fig. 3. No molecular ions were visible. The fragmentation of the trehalose lipid derivative was initiated by the cleavage of the glycosidic bond leading to the rather stable oxonium ions:

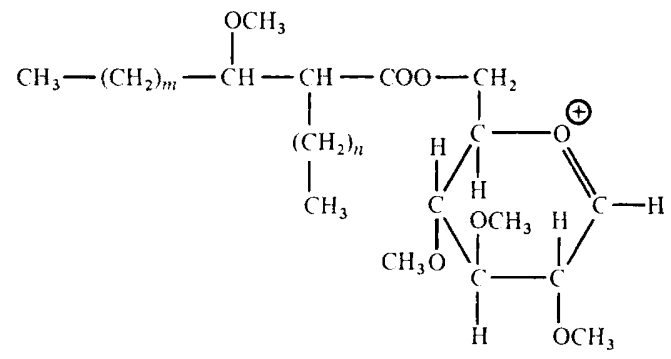

The homologous series of fragments $m / e$ 697, 711, 725, 739, 753, 767 and 781 represent oxonium ions with $m+n=27,28,29,30,31,32$ and 33, consisting of esters of methylated mycolic acids, listed in Table 2, and a permethylated glucose lacking the hydroxyl group at C-1. The fragments of the homologous series $m / e 665,679,693,707,721,735$ and 749 resulted from the loss of methanol from the oxonium ion illustrated above. This methanol was either eliminated from the mycolic acid part giving rise to an $\alpha, \beta$-unsaturated ester or from the sugar moiety leading to a double-bond, probably between C-3 and C-4. The 
Table 3. Composition of the mycolic acids of the trehalose lipid

$\begin{array}{cc}\begin{array}{c}\text { Percentage of } \\ \text { total } \\ \text { mycolic } \\ \text { acids* }\end{array} \\ \text { acid } & 3 \cdot 7 \\ \mathrm{C}_{32} \mathrm{H}_{84} \mathrm{O}_{3} & 13 \cdot 0 \\ \mathrm{C}_{33} \mathrm{H}_{36} \mathrm{O}_{3} & 24 \cdot 2 \\ \mathrm{C}_{34} \mathrm{H}_{68} \mathrm{O}_{3} & 26 \cdot 0 \\ \mathrm{C}_{35} \mathrm{H}_{70} \mathrm{O}_{3} & 19 \cdot 2 \\ \mathrm{C}_{36} \mathrm{H}_{72} \mathrm{O}_{3} & 10 \cdot 2 \\ \mathrm{C}_{37} \mathrm{H}_{74} \mathrm{O}_{3} & 3 \cdot 7 \\ \mathrm{C}_{38} \mathrm{H}_{76} \mathrm{O}_{3} & 3 \cdot 7\end{array}$

* Percentage of permethylated mycolic acids was determined by g.l.c.

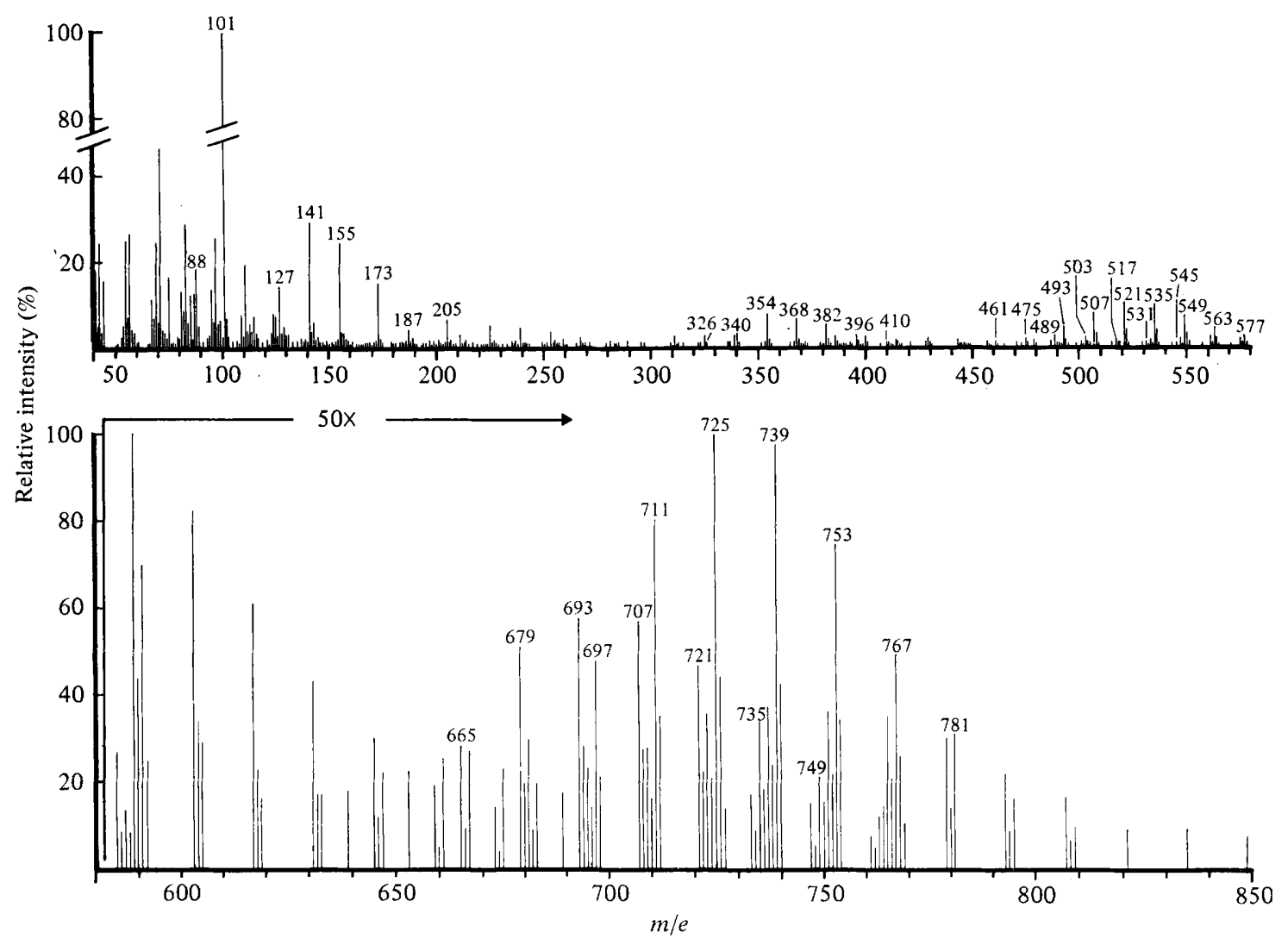

Fig. 3. Mass spectrum of the permethylated trehalose lipid.

homologous series of peaks $m / e 493,507,521,535,549,563$ and 577 were attributable to fragments<smiles>CCC(C#N)C(CC)CC</smiles> 
and another series at $m / e 461,475,489,503,517,531$ and 545 corresponding to fragments

$$
\mathrm{CH}_{3}-\left(\mathrm{CH}_{2}\right)_{m}-\mathrm{CH}=\underset{\left(\mathrm{CH}_{2}\right)_{n}}{\mathrm{C}}-\stackrel{\oplus}{\mathrm{C}}=\mathrm{O}=\quad m+n=27 \text { to } 33
$$

confirmed the composition of the mycolic acids as represented in Table 2 . The composition of the side-chain of the mycolic acids was further confirmed by a homologous series of peaks at $m / e 326,340,354,368,382,396$ and 410 corresponding to fragments

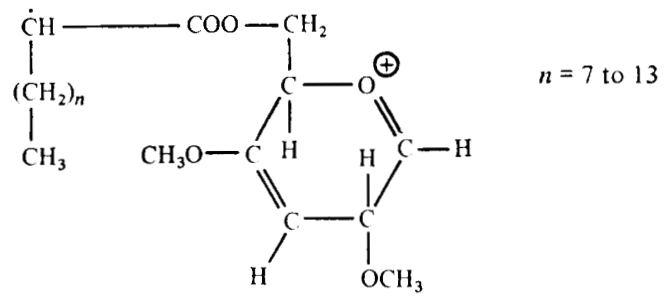

Some peaks due to fragment $a^{\prime}$ could also be observed, but the complete homologous series of peaks ranging from $m / e 311$ to 409 was seen more clearly in the mass spectrum of the permethylated mycolic acids (Fig. 2, Table 2). In the lower mass part of the mass spectrum of the permethylated trehalose lipid a series of peaks could be seen at $m / e 88,101,127,141$, $155,173,187$ and 205, which were attributable to glucose fragments (Radford \& De Jongh, 1972; Ioneda et al., 1970).

\section{Molar ratio of trehalose to mycolates}

The chemical composition of trehalose lipid, determined by elementary analysis, was $71.0 \% \mathrm{C}, 11.49 \% \mathrm{H}$ and $17.51 \% \mathrm{O}$, leading to the formula $\mathrm{C}_{81.12} \mathrm{H}_{157.53} \mathrm{O}_{15}$. Thus, the molar ratio of trehalose to mycolic acids was $1: 2$, taking into account that the most abundant mycolic acids were $\mathrm{C}_{34} \mathrm{H}_{68} \mathrm{O}_{3}$ and $\mathrm{C}_{35} \mathrm{H}_{70} \mathrm{O}_{3}$.

\section{Ester linkages of the mycolic acids to trehalose}

The absence of the peak at $m / e 219$ attributable to

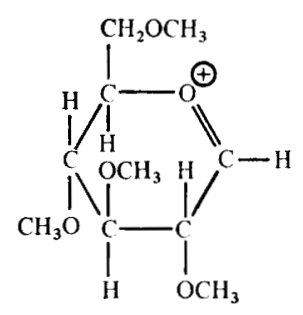

and the presence of a peak at $m / e 205$ corresponding possibly to

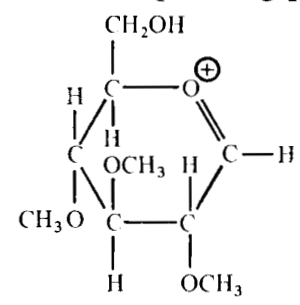

in the mass spectrum of permethylated trehalose lipid (Fig. 3) was evidence for the esterification of one mycolic acid to each glucose moiety of the trehalose. The ion of $m / e 101$ was 


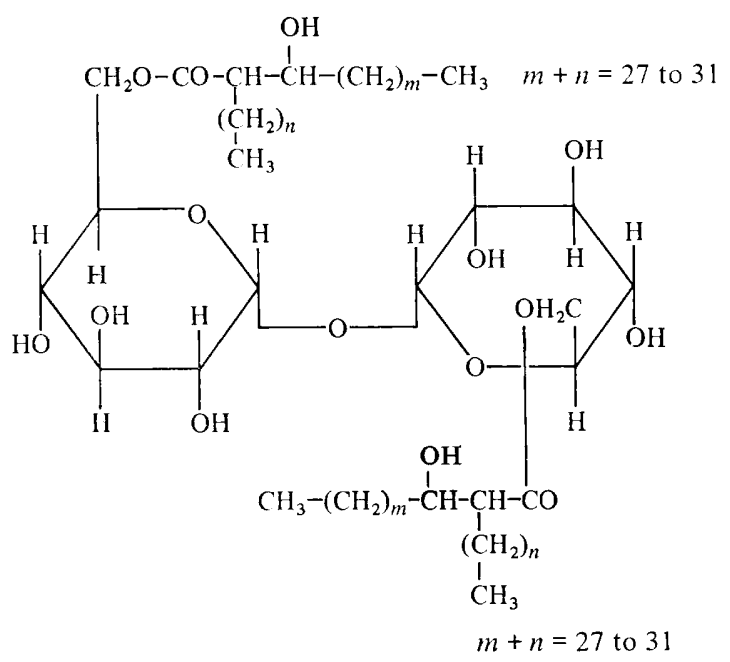

Fig. 4. Structure of the trehalose lipid.

Table 4. ${ }^{13} \mathrm{C}$ nuclear magnetic resonance signals of a hexamethyltrehalose in hexadeuterodimethyl sulphoxide

\begin{tabular}{|c|c|c|c|}
\hline \multirow[b]{2}{*}{ Nucleus } & \multicolumn{2}{|c|}{$\begin{array}{c}{ }^{13} \mathrm{C} \text { chemical shift (p.p.m.) and } \\
\text { multiplicity in SFORD } \\
\text { spectrum* }\end{array}$} & \multirow{2}{*}{$\begin{array}{c}\text { Difference } \\
\text { in chemical } \\
\text { shift }\end{array}$} \\
\hline & Without $\mathrm{D}_{2} \mathrm{O}$ & With $\mathrm{D}_{2} \mathrm{O}$ & \\
\hline C-1 & $92.44 \mathrm{~d}$ & $92.45 \mathrm{~d}$ & +0.01 \\
\hline C-2 & $83 \cdot 39 \mathrm{~d}$ & $83.38 \mathrm{~d}$ & -0.01 \\
\hline C-3 & $81.91 \mathrm{~d}$ & $81 \cdot 87 \mathrm{~d}$ & -0.04 \\
\hline C-4 & $79.75 \mathrm{~d}$ & $79.75 \mathrm{~d}$ & 0.00 \\
\hline C-5 & $72.53 \mathrm{~d}$ & $72 \cdot 50 \mathrm{~d}$ & -0.03 \\
\hline C-6 & $61.03 \mathrm{t}$ & $60 \cdot 88 \mathrm{t}$ & $-0 \cdot 15$ \\
\hline
\end{tabular}

shown by Kochetkov et al. (1963) and Radford \& De Jongh (1972) to consist mainly of C-2, C-3 and C-4 of a permethylated glucose with the suggested structure $\mathrm{CH}_{3} \stackrel{\oplus}{\mathrm{O}}=\mathrm{CH}-\mathrm{CH}=$ $\mathrm{CH}-\mathrm{OCH}_{3}$, and the ion of $m / e 88$ was assumed to be composed predominantly of $\mathrm{C}-2$ and $\mathrm{C}-3$ of a permethylglucose with the possible structure $\mathrm{CH}_{3} \mathrm{O}-\dot{\mathrm{C}} \mathrm{H}-\mathrm{CH}=\stackrel{\oplus}{\mathrm{O}} \mathrm{CH}_{3}$. The appearance of both peaks in the mass spectrum of the permethylated trehalose lipid might therefore be taken as an indication for the ester linkages of the mycolic acids at C-6 and"C- 6 ' of the trehalose.

A final proof for the position of the ester linkages was provided by ${ }^{13} \mathrm{C}$ n.m.r. spectroscopy. The permethylated trehalose lipid was saponified and the trehalose moiety obtained had two free alcohol groups; these were investigated with the aid of ROH to ROD exchange in hexadeuterodimethyl sulphoxide as solvent. Comparison of the spectra obtained before and after shaking the solution with $\mathrm{D}_{2} \mathrm{O}$ showed that one signal had moved upfield by 0.15 p.p.m. (Table 4). This is characteristic of the effect of exchanging protons for deuterium atoms, with two-bond deuterium isotope effects across hetero-atoms being larger than longer range effects (Ladner et al., 1975; Kurobane et al., 1978). This signal was a triplet in the SFORD spectrum and thus corresponds to carbons C- 6 and C- $6^{\prime}$ of the trehalose. Thus, the acyl linkages in the trehalose lipid must be to both primary alcohol groups at the C- 6 and C-6' positions of the trehalose moiety. The structure of the trehalose lipid is shown in Fig. 4. 


\section{DISCUSSION}

Growth and trehalose lipid concentration in a 501 batch culture of Rhodococcus erythropolis DSM 43215 with $n$-alkanes as carbon source did not increase steadily as reported for Arthrobacter paraffineus grown on $n$-alkanes (Suzuki et al., 1969). Clumping of bacteria impeded the uptake of dissolved oxygen and other nutrients by the cells and thus retarded growth and trehalose lipid formation. When the clumps disintegrated to smaller aggregates, growth and trehalose lipid concentration again increased. The subsequent decrease in cell concentration might have been due to cell lysis. The decline in trehalose lipid was probably due to its metabolism; this decline correlated with the $Q_{\mathrm{O}_{2}}$ and $Q_{\mathrm{co} 2}$ values. The clumping of $R$. erythropolis cells grown on $n$-alkanes may be compared to a certain extent with the formation of flocs during the cultivation of Candida tropicalis on $n$-hexadecane (Einsele et al., 1973; Blanch \& Einsele, 1973). However, the clumps formed by $R$. erythropolis DSM 43215 after 10 to $20 \mathrm{~h}$ cultivation were much larger than those from $C$. tropicalis formed under the same conditions of $n$-alkane concentration, aeration and agitation. Indeed, the smaller cell aggregates of $R$. erythropolis, formed by disintegration of the large clumps after about $20 \mathrm{~h}$, were of comparable size to the flocs of $C$. tropicalis (Kretschmer, personal communication).

The trehalose lipid formed by $R$. erythropolis is probably located in the periphery of the cells since it was easily removed from the cells by extraction with $n$-hexane. This solvent extracted fewer unwanted compounds than the often-used chloroform/methanol mixture (Bock, 1979). The yellow pigment extracted together with the trehalose lipid appeared to be a carotenoid on the basis of its ultraviolet spectrum.

The trehalose lipid from $R$. erythropolis can drastically decrease the interfacial tension between $n$-alkane and water, even when it is at a very low concentration (Rapp et al., 1977). This, and the probable induction of trehalose lipid formation by $n$-alkanes, suggests that trehalose dimycolates may play a role in the uptake of $n$-alkanes by $R$. erythropolis. Suzuki et al. (1969) have previously suggested such an involvement of the trehalose lipid in the uptake of hydrocarbons by Arthrobacter paraffineus and some other $n$-alkane-utilizing bacteria. Using highly purified trehalose dimycolates we found that for the emulsification and stabilization of an $n$-alkane/water emulsion at least one additional compound was necessary. This might possibly be a protein-like substance similar to the protein activator formed together with a rhamnolipid by Pseudomonas aeruginosa when growing on $n$-alkanes (Hisatsuka et al., 1971, 1972, 1975, 1977). Also two rhamnolipids isolated by Yamaguchi et al. (1976) from culture filtrates of a Pseudomonas sp. exhibited a strong emulsifying activity in an oilin-water system.

${ }^{13} \mathrm{C}$ n.m.r. spectroscopy and mass spectrometry indicated that the trehalose lipid formed by $R$. erythropolis DSM 43215 is a diester of $\alpha, \alpha$-trehalose linked in the C- 6 and C- 6 ' positions to mycolicacids ranging from $\mathrm{C}_{32} \mathrm{H}_{64} \mathrm{O}_{3}$ to $\mathrm{C}_{38} \mathrm{H}_{76} \mathrm{O}_{3}$. The arrangement of the different mycolic acids in the diesters could not be determined as no molecular peaks in the mass spectra of the permethylated trehalose dimycolates were detected. It was not possible, therefore, to ascertain whether the diesters were homogeneous (containing two identical acids per trehalose unit) or heterogeneous (containing two different acids per trehalose unit). Nor was it possible to determine the number of different trehalose dimycolates in the mixture.

Ioneda et al. (1970) have also isolated trehalose dimycolates with saturated and monounsaturated acids ranging from $\mathrm{C}_{38} \mathrm{H}_{76} \mathrm{O}_{3}$ to $\mathrm{C}_{46} \mathrm{H}_{90} \mathrm{O}_{3}$ from a strain labelled Nocardia rhodochrous grown on glycerol. This organism may possibly also belong to the genus Rhodococcus according to the new classification proposed for actinomycetes previously included in the 'rhodochrous' complex (Goodfellow \& Alderson, 1977). In glucose-grown cells of Nocardia erythropolis, a strain which probably belongs to the taxon Rhodococcus erythropolis (Goodfellow \& Alderson, 1977), Yano et al. (1971) found a compound whose $R_{F}$ value after two-dimensional t.l.c. coincided with that of the cord factor of Mycobacterium tuberculosis. 
Trehalose dimycolates comparable in size with those isolated here were extracted from Nocardia asteroides (Ioneda et al., 1970) and Corynebacterium diphtheriae (Ioneda et al., 1963). The trehalose lipid extracted from $N$. asteroides contained saturated and monounsaturated mycolic acids ranging from $\mathrm{C}_{32} \mathrm{H}_{66} \mathrm{O}_{3}$ to $\mathrm{C}_{36} \mathrm{H}_{72} \mathrm{O}_{3}$ (Ioneda et al., 1970) while the trehalose dimycolate from $C$. diphtheriae contained saturated and mono-unsaturated $\mathrm{C}_{32}$ mycolic acids (Ioneda et al., 1963). Glycolipids with $\mathrm{C}_{32}$ mycolic acids, but esterified at the C-6 of a glucose instead of trehalose, were also detected in both $C$. diphtheriae and Mycobacterium smegmatis when grown on glucose (Brennan et al., 1970). Okazaki et al. (1969) isolated a similar acylglucose, consisting of a di-unsaturated $\mathrm{C}_{36}$ mycolic acid esterified at the C- 6 position of the glucose, from an oleic acid-requiring mutant of Brevibacterium thiogenitalis cultivated on glucose.

We thank Mrs E. Laude and Mrs J. Günther for their skilful technical assistance.

This paper is dedicated to Professor Dr H. Pommer (BASF, Ludwigshafen) on the occasion of his 60 th birthday.

\section{REFERENCES}

Asselineau, C. \& Asselineau, J. (1978). Trehalosecontaining glycolipids. Progress in the Chemistry of Fats and other Lipids 16, 59-99.

BARKSDALE, L. \& KIM, K.-S. (1977). Mycobacterium. Bacteriological Reviews 41, 217-372.

BlanCH, H. W. \& Einsele, A. (1973). The kinetics of yeast growth on pure hydrocarbons. Biotechnology and Bioengineering 15, 861-877.

Bock, H. (1979). Strukturaufklärung and Wirkungsweise eines Glykolipids aus Rhodococcus erythropolis bei n-Alkan-Fermentationen. Ph.D. thesis, Technische Universität Braunschweig, F.R.G.

Bremser, W., ERnst, L. \& Franke, B. (1978). Carbon-13 NMR Spectral Data. Weinheim: Verlag Chemie.

Brennan, P. J., Lehane, D. P. \& Thomas, D. W. (1970). Acylglucoses of corynebacteria and mycobacteria. European Journal of Biochemistry 13, 117-123.

BRoBST, K. M. (1972). Gas-liquid chromatography of trimethylsilyl derivatives. Methods in Carbohydrate Chemistry 6, 3-8.

BRUNNER, R. L. (1964). Determination of reducing value. Methods in Carbohydrate Chemistry 4, 67-71.

Corey, E. J. \& Chaykovsky, M. (1962). Methylsulfinylcarbanion. Journal of the American Chemical Society 84, 866-868.

Einsele, A., Blanch, H. W. \& Fiechter A., (1973). Agitation and aeration in hydrocarbon fermentations. Biotechnology and Bioengineering, Symposium no. 4, pp. 455-466. Edited by B. Sikyta, A. Prokop \& M. Novàk. New York: WileyInterscience.

Goodfellow, M. \& Alderson, G. (1977). The actinomycete-genus Rhodococcus: a home for the 'rhodochrous' complex. Journal of General Microbiology 100, 99-122.

Goodfellow,M., Collins, M. D. \& Minnikin, D. (1976). Thin-layer chromatographic analysis of mycolic acid and other long-chain components in whole-organism methanolysates of coryneform and related taxa. Journal of General Microbiology 96, 351-358.
HAKOMORI, S. I. (1964). A rapid permethylation of glycolipid, and polysaccharide catalyzed by methylsulfinyl carbanion in dimethyl sulfoxide. Journal of Biochemistry 55, 205-208.

Hisatsuka, K. Nakahara, T., Sano, N. \& Yamada, K. (1971). Formation of rhamnolipid by Pseudomonas aeruginosa and its function in hydrocarbon fermentation. Agricultural and Biological Chemistry 35, 686-692.

Hisatsuka, K., Nakahara, T. \& Yamada, K. (1972). Protein-like activator for $n$-alkane oxidation by Pseudomonas aeruginosa $\mathrm{S}_{7} \mathrm{~B}_{1}$. Agricultural and Biological Chemistry 36, 1361-1369.

Hisatsuka, K., Nakahara, T., Minoda, J. \& YAMADA, K. (1975). Capacity to oxidize $n$-alkane in EDTA-treated cells of Pseudomonas aeruginosa $\mathrm{S}_{7} \mathrm{~B}_{1}$. Agricultural and Biological Chemistry 39, 999-1005.

Hisatsuka, K., Nakahara, T., Minoda, J. \& YAMADA, K. (1977). Formation of protein-like activator for $n$-alkane oxidation and its properties. Agricultural and Biological Chemistry 41, 445-450.

Hodge, J. E. \& Hofreiter, B. T. (1962). Determination of reducing sugars and carbohydrates. Methods in Carbohydrate Chemistry 1, 380-394.

IonedA, T., Lenz, M. \& Pudles, J. (1963). Chemical constitution of a glycolipid from $C$. diphtheriae P.W. 8. Biochemical and Biophysical Research Communications 13, 110-114.

IONEDA, T., LEDERER, E. \& RozANIS, J. (1970). Sur la structure des diesters de trehalose ("cord factors') produits par Nocardia asteroides et Nocardia rhodochrous. Chemistry and Physics of Lipids 4, 375-392.

Kamerling, J. P., Rosenberg, D. \& Vliegenthart, J. F. G. (1970). The determination of the configuration of the glycosidic link in oligosaccharides by P.M.R. spectroscopy of trimethylsilyl derivatives. Biochemical and Biophysical Research Communications 4, 794-799.

Kanetsuna, F. \& Bartoli, A. (1972). A simple chemical method to differentiate Mycobacterium from Nocardia. Journal of General Microbiology 70, 209-212. 
Kochetkov, N.K., Wulfson, N.S., Chizhov, O. S. \& Zolotarev, B. M. (1963). Mass spectrometry of carbohydrate derivatives. Tetrahedron 19 , 2209-2224.

Krebs, K. G., Heusser, D. \& Wimmer, H. (1967). Sprühreagentien. In Dünnschichtchromatographie pp. 813-859. Edited by E. Stahl. Berlin: Springer Verlag.

Kurobane, I., Vining, L. C. \& McInnes, A. G. (1978). A new secalonic acid. Linkage between tetrahydroxanthone units determined from deuterium isotope ${ }^{13} \mathrm{C}$ chemical shifts. Tetrahedron Letters, 4633-4636.

LADNER, H. K., Led, J. J. \& Grant, D. M. (1975). Deuterium isotope effects on ${ }^{13} \mathrm{C}$ chemical shifts in amino acids and dipeptides. Journal of Magnetic Resonance 20, 530-534.

LEDERER, E. (1967). Glycolipids of mycobacteria and related microorganisms. Chemistry and Physics of Lipids 1, 294-315.

LEDERER, E. (1976). Cord factor and related trehalose esters. Chemistry and Physics of Lipids 16, 91-106.

Minnikin, D. E. \& Goodfellow, M. (1976). Lipid composition in the classification and identification of nocardiae and related taxa. In The Biology of the Nocardiae, pp. 160-219. Edited by M. Goodfellow, G. H. Brownell \& J. A. Serrano. London: Academic Press.

Minnikin, D. E., Alshamaony, L. \& Goodfellow, M. (1975). Differentiation of Mycobacterium, Nocardia and related taxa by thin-layer chromatographic analysis of whole-organism methanolysates. Journal of General Microbiology 88, 200-204.

OKazaki, H., Sugino, H., Kanzaki, T. \& Fukuda, H. (1969). L-Glutamic acid fermentation. Part VI. Structure of a sugar lipid produced by Brevibacterium thiogenitalis. Agricultural and Biological Chemistry 33, 764-770.

RAdFord, T. \& De Jongh, D. C. (1972). Carbohydrates. In Biochemical Application of Mass Spectrometry, pp. 313-350. Edited by G. R. Waller. New York: Wiley-Interscience.
RAPP, P. \& WAGNER, F. (1976). Formation of trehalose lipid by Nocardia rhodochrous sp. grown on n-alkane. In $V$. International Fermentation Symposium, Abstract of Papers, p. 133. Edited by H. Dellweg. Berlin: Verlag Versuchsund Lehranstalt für Spirituosenfabrikation und Fermentationstechnologie im Institut für Gärungsgewerbe und Biotechnologie.

RAPP, P., BOCK, H., URBAN, E., WAGNER, F., Gebetsberger, W. \& Schulz, W. (1977) Mikrobielle Bildung eines Trehaloselipids und seine Anwendung in Modellversuchen zum Tensidfluten von Erdöllagerstätten. Dechema-Monographien 81, 177-186.

Schilling, G., Henkels, W.-D., Künstler, K. \& WEINGES. K. (1975). Zur Konstitutionsermittlung der $\mathrm{C}_{15}$-Iridoidglucoside und ihrer natürlichen Derivate mit Hilfe der ${ }^{13} \mathrm{C}$-NMR-Spektroskopie. Justus Liebigs Annalen der Chemie, 230-239.

Senn, M., Ioneda, T., Pudles, J. \& Lederer, E. (1967). Spectrometrie de masse de glycolipides. European Journal of Biochemistry 1, 353-356.

STOTHERS, J. B. (1972). Carbon-13 NMR Spectroscopy. London: Academic Press.

Suzuki, T., Tanaka, K., Matsubara, I. \& KinoSHITA, S. (1969). Trehalose lipid and $\alpha$-branched$\beta$-hydroxy fatty acid formed by bacteria grown on $n$-alkanes. Agricultural and Biological Chemistry 33, 1619-1627.

WAgner, F., RAPP, P., Lindörfer, W., Schulz, W. \& Gebetsberger, W. (1978). Verfahren zum Fluten von Erdöllagerstätten mittels Dispersionen nichtionogener grenzflächenaktiver Stoffe in Wasser. German Patents DE-2646505, DE2646506, DE-26 46507.

Yamaguchi, M., Sato, A. \& Yúuyama, A. (1976). Microbial production of sugar-lipids. Chemistry and Industry, 741-742.

Yano, I., Furukawa, J. \& Kúsunose, M. (1971). Occurence of acylated trehaloses in Nocardia. Journal of General and Applied Microbiology 17, 329-334. 